\title{
SELECTION OF POST LABOR CONTRASEPTION IN SUCI VILLAGE PANTI JEMBER
}

\author{
Zuhrotul Eka Yulis Anggraini \\ Faculty of Health Science, University of Muhammadiyah Jember \\ Corresponding e-mail : yulisanggraeni@gmail.com
}

\begin{abstract}
ABSTRAK
BACKGROUND: family planning $(\mathrm{KB})$ is one of the efforts made to prevent pregnancy, both traditionally and modernly which aims to improve the welfare of mother and her child and realize the nirms of small, happy and prosperous familirs that are the basis for the realizaton of a prospeorus society through birth control and control population growth. Post delivery is a transition period to determine contraception. The space between pregnancy and childbirth is important for the health of the mother and child. It is a resting phase in waiting for the recovery phase. This study aims to determine the description of postpartum contraceptive choice and background of the selection.
\end{abstract}

SUBJECT AND METHODE : this study is a descriptive explorative study involving 33 mother who has baby aged 6 months old in Posyandu in Suci Village.

RESULT : the age of most respondents is the age of healthy reproduction that is $20-35$ old; most respondents are graduated from elementary school and senior high school and their activity is become a housewife; most of respondents are multiparous; all respondents choose injection contraception since it is easy and practice to use.

DISCUSSION : selection of injectional contraceprtion by all respondents is a reproductive right of women that must be respected. Easy and practical injection applications an a long period of time that is 3 months make respondents choose injection contraception compared to other contraceptives.

Key words : injectional contraception, post delivery

\section{INTRODUCTION}

Population problem is a problem faced by all countries both developed and developing countries, including Indonesia, this can be seen froem the worls population which is increasing rapidly with a higher population growth rate. To reduce the rate of population growth, the goverment conducted a national Family Planning Program (Murdiyanti, 2007). Population control is done through the family planning program (KB). The family planning program is carried out to spell out, delay and stop pregnancy or fertility. Contraception comes form the words counter which means to prevent or fight, while conception means the meeting between a mature egg cell wich results in pregnancy. So the notion of contraception is to avoid/prevent pregnany due to the conseption of mature egg cell and sperm cell (BKKBN, 2005).

Family planning $(\mathrm{KB})$ is one of the efforts made to prevent pregnancy, both traditionally and modernly, the aims of which is to improve the welfare of mothers and children and realize the norms of small, happy and propserous families that are the basis for the realization of a prosperous society through birth control and control population grow (Arum, NS, Dyah, 2001). Post delivery is a transition period to determine contraception. The distance between preganncy and childbirth is important for 
the health of the mother and child. Post partum mother is a resting phase in waiting for the recovery phase.

Postpartum periode is a period that begins after labor is over and ends for about 6 weeks. However the entire uterine uterus will recover to its state before pregnancy within 3 months. Ideally couple must wait at least 2 years to get pregnant again (Prawirohardjo, 2005). Consultation of contraception in the post partum period is improtant to regulate the space of pregnancy, provide education to mothers about the forms of contraception, and also when it is safe to be able to return to having sex. The right choice of contraception requires knowledgeof patients motivation and the eefficacy, safety, and ease of vaious contracepeptives (Rayburn, 2001). Therea are several types of contraceotion that mothers can choose during the postpartum period. Examples include mini pill, IUD, implant, injection contraception, lactation amenorrhoea method and etc. In this case, a mother must also be observant in seeing the level of effectiveness of contraception and its effect on lactation (Saifuddin, 2005). Based on the background above, the author conduct this study to describe the selection of contraception device among reproductive women in Suci village.

\section{METHODE}

This study is decriptive explorative methode. This study involving 33 respondents which is a mother who has baby aged 6 months old and having contraception and do some asessment in Posyandu. The respondents are taken by total sampling.

\section{RESULTS AND DISCUSSION}

Table 1. Characteristic of Respondent by The Age

\begin{tabular}{ccc}
\hline Age & Frequency & Percentage \\
\hline$<20$ years old & 3 & $9 \%$ \\
$20-35$ years old & 21 & $64 \%$ \\
$>35$ years old & 9 & $27 \%$ \\
\hline Total & 33 & $100 \%$ \\
\hline
\end{tabular}

According to the table above it can be seen that most respondents are $20-5$ years old as many as 21 people $(64 \%)$.

Age is a factor that has improtant role in the choice of contraception. Based on the results of the study most respondents had ages between 20 to 35 years . categorically the age of respondents is in the range of adult and healthy reproduction so taht in the selection of contraception it can be said to be mature and behave. Another condition that must be considered is the healthy reproduction period, so this condition ia a golden period of reproduction. This in line with with research conducted by Bernadus et al (2013) which is stated that increasing age of an individuals is said to be more mature in mind and behavior. Age above 20 years is period of sparing and preventing pregnancy so that the choice of cintraception is more aimed at long term of contraception.

Table 2. Characteristic of Respondent by the Education

\begin{tabular}{ccc}
\hline Education & Frequency & Percentage \\
\hline SD & 11 & $33 \%$ \\
SMP & 9 & $27 \%$ \\
SMA & 11 & $33 \%$
\end{tabular}




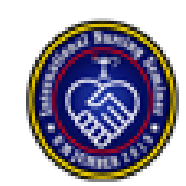

\begin{tabular}{ccc} 
Sarjana & 2 & $7 \%$ \\
\hline Total & 33 & $100 \%$ \\
\hline According o the table above we see that most respondents are graduated from elementary
\end{tabular}

According 0 the table above we see that most respondents are graduated from elementary school and senior high school.

Education has an important role in performing behavior, especially realted to health. The results of the study showed that only a small proprotions possessed undergraduated education and the majority of respondents education was elementary and high school. Behavior in choosng certainly has a background one of which is education. One's education is very decisive in one's thought process. Provision of information when in school will shape the character of each individual and ultimately will have an impact on behavior.

Table 3. Characteristic of Respondents by The Occupation

\begin{tabular}{ccc}
\hline Occupation & Frequency & Percentage \\
\hline Housewife & 30 & $91 \%$ \\
Farmer & 1 & $3 \%$ \\
Trader & 1 & $3 \%$ \\
Teacher & 1 & $3 \%$ \\
\hline & 33 & $\mathbf{1 0 0 \%}$
\end{tabular}

Based on table we can see that majority of respondents are housewives. Occupation is a supporting factors of someone in carrying out a behavior. The results showed that most respondents were housewives. Housewives spend more time at home. In contrast to working mothers. Intraction done by the mothers with others is more limited. This condition is supported by education that is still low and the location of areas that are not urban areas, so mothers rerly interact with the outside world. Provision of infomation obtained from health workers.

Table 4. Characteristic of Respondents by Parity

\begin{tabular}{ccc}
\hline Parity & Frequency & Percentage \\
\hline 1 & 15 & $45 \%$ \\
$2-3$ & 17 & $51 \%$ \\
$>3$ & 1 & $4 \%$ \\
\hline & 33 & $100 \%$
\end{tabular}

According to table 4, most repsondents are multipara. Parity is the number of live births. The higher parity ilustrates that the thinning proccess or familiy planning is lower. Based on the results of the study most of the respondents have parity $2-3$ or are categorized multipara. The experience of the first child in the selection of contraception will certainly have an influence on the choice of further contraception. Angoi (2012) in Semarang stated that there was a significant relationship between parity (number of children) and contraceptive seelection.

Table 5. Contraception Selection After Post Partum Periode

\begin{tabular}{ccc}
\hline Selection Contraseption & Frequency & Percentage \\
\hline Injection & 33 & $100 \%$ \\
Pil & 0 & 0 \\
IUD & 0 & 0 \\
Condom & 0 & 0 \\
Implant & 0 & 0 \\
MOW & 0 & 0 \\
MOP & 0 & 0
\end{tabular}




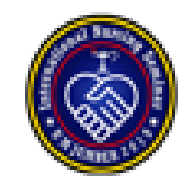

\begin{tabular}{ccc} 
Abstinence periodically & 0 & 0 \\
\hline & 33 & $100 \%$ \\
\hline
\end{tabular}

According to table 5 can be seen that all of respondents choose injection for their contraseption. The choice of postpartum contraception is something that must be done. This is useful in the process of thinning children. Based on the results of the study all respondents chose injection contraception. This condition shows that the respondentsalready has the awareness to choose independently the best contrception shows a positive behavior in the respondent. The level of education, experience, occupation, and age all have a role. In the process of choosing injection contraception, of course the factors above have their respevtive roles, which contribute to building a positive behavior. Many of the reason chosen by respondents why all respondents chose injection contraception as if discussed in the next chapter.

Table 6. The Reason of Contraseption Choosen

\begin{tabular}{ccc}
\hline Reasoning & Ferquency & Percentage \\
\hline Breat feeding & 5 & 15 \\
Menstruation smoothly & 3 & 10 \\
Easy to remember & 9 & 27 \\
Easy and practical & 12 & 36 \\
Suitable & 4 & 12 \\
\hline & 33 & $\mathbf{1 0 0 \%}$ \\
\hline
\end{tabular}

Based on table 6 most of respondents choose the contraception because the ease and practical. The background of selection certainly affect the action of a behavior. In this study the reason for choosing injection contraception are easy and practical. This condition can be understood because injecting contraception has characteristics performed every 3 minths and 1 month is different from pill contraception. The pill must be taken every day so that the acceptors experience forgetting to drink it will be very possible so that contraceptive failure can occur. IUD contraception has weaknesses that must be inserted into the womb so how many people have their own worries even though the time period is very efficient.

\section{CONCLUSION AND RECOMMENDATION}

All respondents choose the injectional contraception since it is easy and practical. From the result the authors recommend to helath prvider to improved health education about contraseption so that the community understanding is better. Contraception is the reproductive rights of every individual. Injectable contraception is ahormonal contraceptiive which also has side effects when used on women over the age of 35 years. So for acceptors aged over 35 years, respondents should change to other contraceptives.

\section{REFERENCE}

Manuaba, I. A. C., Manuaba I. B. G. 2009. Memahami Kesehatan Reproduksi Wanita. Jakarta. EGC.

Murdiyanti, D. 2007. Perbedaan Siklus Mentrruasi Ibu Yang Menggunakan IUD Dengan Kontrasepsi Suntik Di Desa Sidoagung Godean Sleman Yogyakarta. Yogyakarta. 
Prawirohardjo, S. 2009. Ilmu kebidanan. Jakarta. Bina Pustaka Sarwono

Saifuddin, A. B. 2006. Buku Panduan Praktis Pelayanan Kontrasepsi. . Jakarta. Bina Pustaka Sarwono Prawirohardjo.

Bernadus, Johana D. Madianung Agnes. Masi Gresty,. 2013 Faktor-Faktor Yang Berhubungan Dengan Pemilihan Alat Kontrasepsi Dalam Rahim (Akdr) Bagi Akseptor Kb Di Puskesmas Jailolo Jurnal e-NERS (eNS), Volume 1, Nomor 1, Maret 2013, hlm. 1-1 